\title{
地下街の耐震性に対する高層ビルの 地震時挙動の影響
}

\author{
有賀義明 $^{1} \cdot$ 平野悠輔 $^{2} \cdot$ 猪子敬之介 $^{3} \cdot$ 竹内幹雄 $^{4} \cdot$ 小黑明 $^{5} \cdot{\text { 浅賀裕之 } \text { ～}^{6} \text { 村上正明 }}^{7}$ \\ 1弘前大学大学院理工学研究科教授 \\ （一036-8561 青森県弘前市文京町3） \\ E-mail: y-a-arig@cc.hirosaki-u.ac.jp \\ 2 東京工業大学大学院（干226-8502 神奈川県横浜市緑区長津田町 4259-G3-10） \\ E-mail: hirano.y.af@m.titech.ac.jp \\ 3 札幌市建設局土木部（ $=060-8611$ 札幌市中央区北 1 条西 2 丁目） \\ E-mail: keinosuke.inoko@city.sapporo.jp \\ ${ }^{4}$ 株式会社日水コン（†163-1122 東京都新宿区西新宿 6-2-1） \\ E-mail: takeutim@nissuicon.co.jp \\ 5 株式会社日水コン（テ163-1122 東京都新宿区西新宿 6-2-1） \\ E-mail: oguro_a@nissuicon.co.jp \\ ${ }^{6}$ 株式会社 JP ビジネスサービス（率135-8451 東京都江東区深川 2-2-18） \\ E-mail: asaka@jpbs.co.jp \\ ${ }^{7} \mathrm{JIP}$ テクリイエンス株式会社（一 103-0025 東京都中央区日本橋茅場町 1-2-5） \\ E-mail: muraka@cm.jip-ts.co.jp
}

\begin{abstract}
地上に比べて地下では地震動の加速度振幅が小さい傾向があるため, 一般に, 地下は地上よりも耐震上 有利であると思われている．しかし，地盤や構造物の地震時の相互影響によっては，地震動が増幅したり， 構造物の地震時安全性に大きな影響が生じたりする可能性があると推察される. そこで, 地下に地下街が あり, 地下街の両側に高層ビルが建っている場合を想定して三次元動的解析を行い, 高層ビルの地震時挙 動が地下街の耐震性にどのような影響を及ぼすかについて検討した。 その結果, 地下街の両側に建ってい る高層ビルは, 互いに逆位相で挙動することがあり, その場合, 地下街と高層ビルの接続部では大きな地 震時応力が発生することを確認することができた。
\end{abstract}

Key Words : Seismic safety, mutual effects, 3-D dynamic analysis, underground shopping arcade, high buildings

1.はじめに

世界有数の地震被災国である我が国では，地上空 間，地下空間を問わず，大地震時の安全性の確認と 確保は非常に重要な課題である。一般に，地上に比 べて, 地下では地震動の加速度振幅が小さい傾向が あるため，地下は地上よりも耐震上有利であると思 われている。 しかし, 地下の地盤構造によっては地 震時の加速度や変位が特異な増幅を示したり減衰を 示したりすることが想定される ${ }^{1)}$. また, 従来, 構 造物の耐震設計は, 隣接する構造物の影響は考慮せ ず，個別に独立して行われるのが通例であるが，隣 接する構造物との地震時の相互影響によっては耐震 性に大きな影響が発生することが想定される ${ }^{2)}$.
このような観点から，地下構造物と地上構造物の 地震時の相互影響を明らかにし, 隣接する構造物の 相互の影響を考慮した耐震性能照査技術と地震対策 技術を確立することを最終目標として，ここでは， 地下に地下鉄と地下街があり, 地下街の両側に高層 ビルが建っている場合を想定して三次元動的解析を 行い, 地下街の耐震性に対する高層ビルの地震時挙 動の影響について考察した。

\section{2．地下における地震災害事例}

地下空間に関連した地震による被害事例としては, 1995 年兵庫県南部地震による地下鉄大開駅の中柱の 
破壊が良く知られている ${ }^{3)}$. 神戸高速鉄道大開駅で は, 鉄筋コンクリート造の中柱が崩壊し, その上に 位置していた，地表の国道 2 号線は約 $2 \mathrm{~m}$ 陥没した. 兵庫県南部地震による地下鉄の地震被害は, 市営地 下鉄長田駅や上沢駅でも報告されている.

1985 年メキシコ地震では, 21 階建鉄骨造の高層 ビルの倒壊事例が報告されている ${ }^{4)}$ 。この高層ビル の直下には, 地下鉄が走っており, ビルの地下部を 貫通していた．この高層ビルの倒壊の原因は, 下層 階の組立ボックス柱における溶接不良による局部座 屈であると報告されており，地下鉄と高層ビルの地 震時の相互影響については不明であるが, 地下構造 物と地上構造物の相互影響の可能性について検討す る際の参考事例になるものと考えられる.

\section{3. 研究の必要性と目的}

大深度地下の公共的使用に関する特別措置法 ${ }^{5)}$ が 2001 年 4 月に施行され, 都市の再生, 都市交通網の 整備, 都市水害の予防施設等に関連して, 様々な地 下空間の利用が図られるようになり，大都市では， 地下鉄や地下街, 地下自動車道, 地下河川等の開発 が進んでいる. 地下街や地下鉄に関しては, 出入り 口や通路が周辺のビルと接続されている事例も多い. 札幌, 仙台, 東京, 横浜, 名古屋, 京都大阪, 福岡 等の大都市では, 毎日, 数多くの市民が日常生活の 中で頻繁に地下街や地下鉄を利用している.

構造物の耐震設計は, 従来, 個々の構造物のみに 着目して行われるのが通例であり, 隣り合う構造物 の間の相互の影響は考慮しないのが通例である. 地 上構造物と地下構造部の接続部は, 地震時の応答特 性や变位挙動特性が異なったり変化したりする部位 に相当するため, 地震時には応力集中や相対変位等 によって損傷や破壊を受けやすい部位になるものと 想定される. しかし, 地下構造物と地上構造物の接 続部の耐震性能照査法や地震対策法に関しては, ま だ十分に確立されていないのが現状であると考えら れる. 我が国では, 大都市の多くは広大で軟弱な堆 積平野に分布しているため, 将来の発生が想定され ている大地震時には, 地震動の増幅 - 長周期化・長 時間化, 地盤の破壊や流動, それらに起因する構造 物の損傷・破壊, 地震災害の連鎖等が懸念される. 様々な地盤・構造物系の複合体として構成される, 大都市の地震時安全性を向上させるためには, 個々 の構造物のみに着目した耐震性能照査ではなく, 隣 接する構造物間の相互の影響を考慮した耐震性能照 査が必要になると考えられる.
このような考えから, 本研究では, 三次元動的解 析を用いて, 高層ビルの地震時の変位挙動が地下街 の応力状態にどのような影響を及ぼすかについて解 析的検討を行い考察した.

\section{4. 三次元動的解析}

\section{(1) 概要}

地下構造物と地上構造物の接続部での地震時の相 互影響を検討するために，地下鉄と地下街と高層ビ ルを配置した解析モデルを作成し三次元動的解析を 行った. 地下街と高層ビルが地下で接続されている 場合, 地下街と高層ビルの接続部で発生する地震時 応力は, 高層ビルの地震時挙動によって変化するも のと想定される。 そこで, 地震被害が発生しやすい と想定される, 地下街と高層ビルの接続部に着目し て, 高層ビルの地震時挙動が接続部の地震時応力に どのような影響を及ぼすかについて考察した. 三次 元動的解析には, 解析プログラム DIANA を使用し た.

\section{（2）三次元動的解析モデル}

解析対象は, 大都市の堆積地盤に建設された, 地 下鉄と地下街と高層ビルを想定して図-1 と図-2に 示したような条件を設定した。

地下構造物に関しては, 地表から土被り $5 \mathrm{~m}$ の位 置に地下街があり, その下に地下鉄が位置している 条件を設定した。地上構造物に関しては, 地下街の 両側に高さ $60 \mathrm{~m}$ の地上 12 階建の高層ビルが建って いる状況を設定した. 地下街, 地下鉄および高層ビ ルの主な寸法は, 表-1に示すとおりである.

表-1 地下街および高層ビルの主な寸法

\begin{tabular}{|c|c|c|c|c|}
\hline \multirow{2}{*}{ 構造物 } & \multirow{2}{*}{ 幅 } & \multicolumn{2}{|c|}{ 高さ } & \multirow{2}{*}{ 奥行 } \\
\cline { 3 - 4 } & & 地上 & 地下 & \\
\hline 高層ビル $\mathrm{A}$ & $50 \mathrm{~m}$ & $60 \mathrm{~m}$ & $15 \mathrm{~m}$ & $20 \mathrm{~m}$ \\
\hline 高層ビル B & $30 \mathrm{~m}$ & $60 \mathrm{~m}$ & $15 \mathrm{~m}$ & $40 \mathrm{~m}$ \\
\hline 地下街 & $40 \mathrm{~m}$ & \multicolumn{2}{|c|}{$5 \mathrm{~m}$} & $200 \mathrm{~m}$ \\
\hline 地下鉄 & $14 \mathrm{~m}$ & \multicolumn{2}{|c|}{$5 \mathrm{~m}$} & $200 \mathrm{~m}$ \\
\hline
\end{tabular}

一般的に, 高層ビルの固有周期は, 概ね階数 $\times$ 0.1 (秒) 程度になると考えられるので, ここでは, 高層ビルの短辺方向の一次固有周期を 1.2 秒と仮定 した.なお，地下街の両側に建つ 2 棟の高層ビルの 平面形状と長辺方向を変化させた理由は, 2 棟の高 層ビルの変位挙動が同位相になったり逆位相になっ 
たりする状況を模擬するためである.

解析に用いた有限要素モデルは，図-3（全体モデ ル）と図-4（中央の横断面）に示すとおりである. 地下鉄, 地下街, 高層ビルは, いずれもソリッド要 素を用いてモデル化した．高層ビルは，梁と柱によ って構成されるモデルとした，高層ビルと地下街の 接続部に関しては, 地下街の側壁がない空間として モデル化した，基礎地盤に関しては，4 層の水平成 層地盤を仮定して, 横 $300 \mathrm{~m}$, 奥行 $240 \mathrm{~m}$, 深さ $50 \mathrm{~m}$ の範囲をソリッド要素でモデル化した．解析モデル の側方境界は粘性境界, 下方境界は剛基盤を設定し た. 解析モデルの節点数は 35,080 , 要素数は 30,880 である.

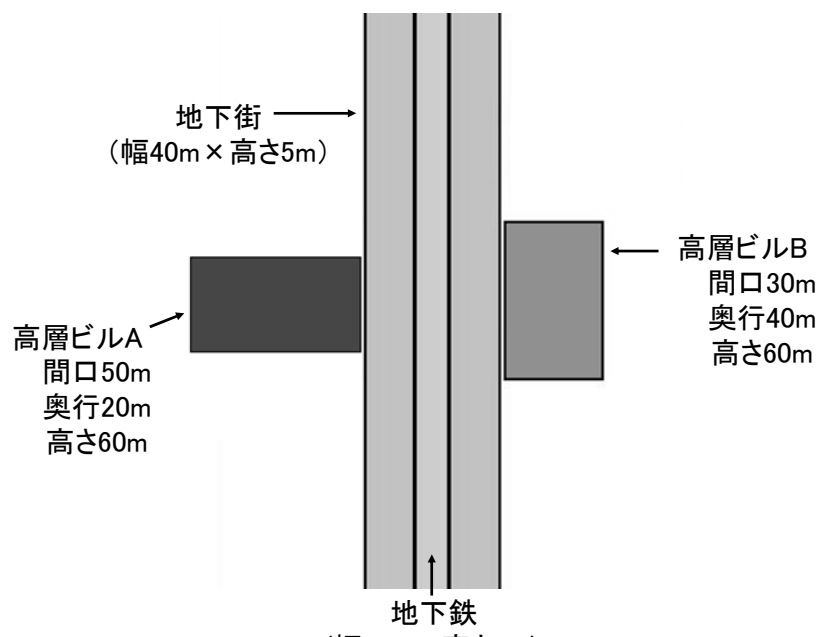

（幅 $14 \mathrm{~m} \times$ 高さ $5 \mathrm{~m}$ )

図-1 想定した解析対象の平面配置

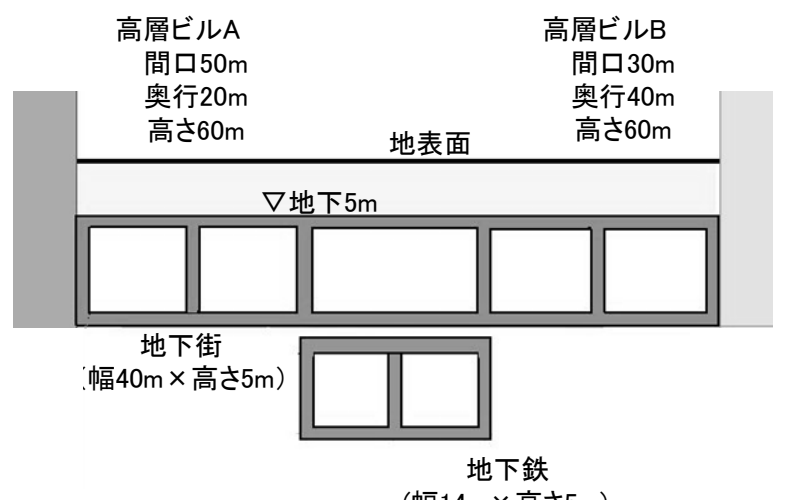

（幅 $14 \mathrm{~m} \times$ 高さ $5 \mathrm{~m}$ )

図-2 想定した解析対象の横断面

地下鉄と地下街と高層ビルの動的物性值は表-2 に示すと扔りである. 地下鉄と地下街は, 鉄筋コン クリート造を想定した. 高層ビルの動的せん断剛性 の值は, 予備解析を実施し一次固有周期が 1.2 秒に なった際の值を設定し, 地上部も地下部も同じ值を 仮定した. 減衰定数については，一般的な值として
3\%を仮定した，地盤に関しては，表-3 に示したよ うな動的物性值を設定した。地盤の $\mathrm{S}$ 波速度につい ては，高層ビルを直接基礎として設定しているため 良好な地盤を想定し, 表層では $400 \mathrm{~m} / \mathrm{s}$, 基盤では $700 \mathrm{~m} / \mathrm{s}$ の值を仮定した．地盤の減哀定数については, 強震時の非線形効果を念頭に置き，一般に想定され る值よりもやや大きい值として 5\%と 3\%を仮定した.

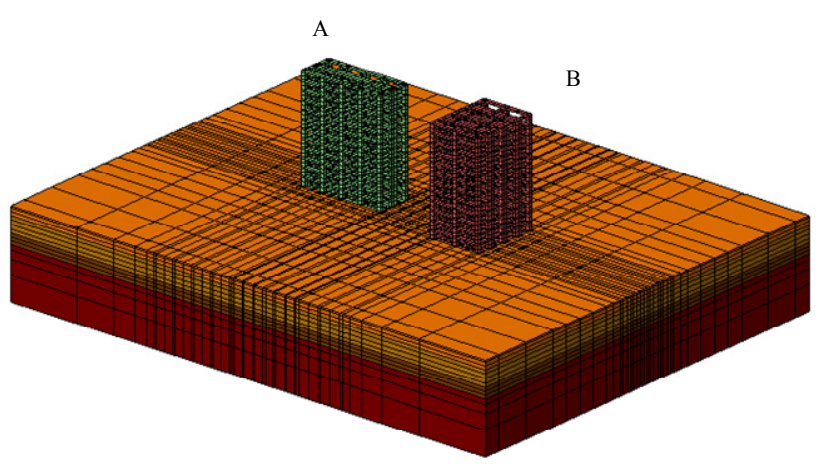

図-3 三次元解析モデル（全体モデル）

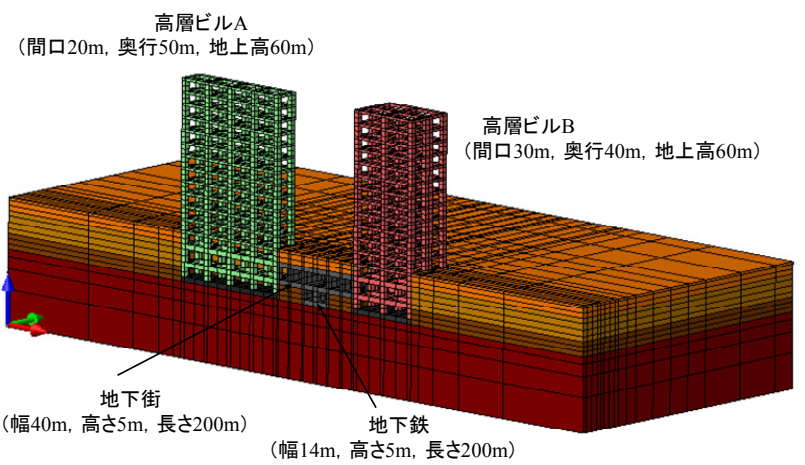

図-4 解析モデルの中央の横断面

表-2 地下および地上構造物の動的物性值

\begin{tabular}{|c|c|c|c|}
\hline \multirow{2}{*}{ 項目 } & \multicolumn{2}{|c|}{ 高層ビル } & \multirow{2}{*}{$\begin{array}{c}\text { 地下街 } \\
\text { 地下鉄 }\end{array}$} \\
\cline { 2 - 3 } & $\mathrm{A}$ & $\mathrm{B}$ & 9000 \\
\hline せん断剛性 $\left(\mathrm{N} / \mathrm{mm}^{2}\right)$ & 6700 & 6700 & 2.3 \\
\hline 密度 $\left(\mathrm{g} / \mathrm{cm}^{3}\right)$ & 2.3 & 2.3 & 0.2 \\
\hline ポアソン比 & 0.2 & 0.2 & 0.03 \\
\hline 減哀定数 & 0.03 & 0.03 & \\
\hline
\end{tabular}

表-3 地盤の動的物性值

\begin{tabular}{|c|c|c|c|c|c|}
\hline $\begin{array}{c}\text { 層 } \\
\text { No. }\end{array}$ & $\begin{array}{c}\text { 層厚 } \\
(\mathrm{m})\end{array}$ & $\begin{array}{c}\mathrm{S} \text { 波速度 } \\
(\mathrm{m} / \mathrm{s})\end{array}$ & $\begin{array}{c}\text { 密度 } \\
\left(\mathrm{g} / \mathrm{cm}^{3}\right)\end{array}$ & $\begin{array}{c}\text { ポアソ } \\
\text { ン比 }\end{array}$ & $\begin{array}{c}\text { 減衰 } \\
\text { 定数 }\end{array}$ \\
\hline 1 & 5 & 400 & 2.1 & 0.40 & 0.05 \\
\hline 2 & 9 & 500 & 2.2 & 0.35 & 0.05 \\
\hline 3 & 6 & 600 & 2.3 & 0.35 & 0.05 \\
\hline 4 & 30 & 700 & 2.5 & 0.25 & 0.03 \\
\hline
\end{tabular}


強震時の動的解析では, 動的せん断剛性と減衰定 数のひずみ依存性を考慮した解析を行うことが望ま しいが, ここでは, 地下街と高層ビルの地震時の相 互影響をより単純化して検討することに主眼を置い て, 解析は線形解析として行った. なお, 動的せん 断剛性の值は, 本解析と同じ入力地震動を用いた予 備解析結果に基づいて設定したものである.

\section{（3） 入力地震動}

入力地震動は, 土木学会コンクリート標準示方書 耐震性能照査編(6)に例示されているL2地震動基盤波

（L2スペクトル II）を使用した. 図-5に示したよう に，本解析では，波形の0秒から15秒までの区間を 使用し，下方基盤から入力した. 入力地震動の最大 加速度振幅は，749.6galである．地下街や地下鉄等 の線状構造物に関しては, 一般的に, 長軸方向（縦 断方向）よりも短軸方向（横断方向）の方が地震動 の影響が大きいと想定されることから，ここでは， 解析モデルの短軸方向（横断方向）に地震動を入力 した.

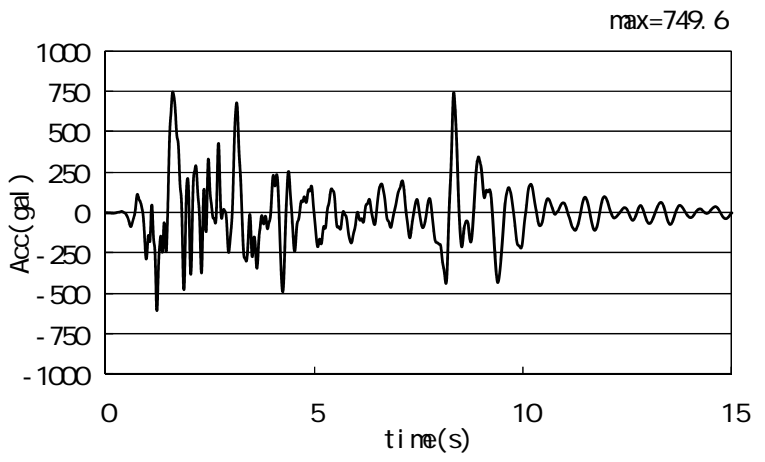

図-5 入力地震動

\section{（4）解析結果}

最大加速度応答, 高層ビルの変位挙動, 地下街と 高層ビルの接続部の地震時応力に関する解析結果を 以下に示す。

\section{a) 最大加速度応答}

図-5 に示した入力地震動を地下街の横断方向に 作用させた場合の時刻 3.43 秒における最大加速度分 布を図-6に示す．図-6 は, 高層ビル A の加速度が 最大になった時刻の最大加速度分布であり, 高層ビ ル A の頂部における最大加速度応答は 3693.5gal で あった. 同様に, 時刻 8.69 秒における最大加速度分 布を図-7 に示す. 高層ビル B の頂部における最大 加速度応答は 3693.5gal であった。 なお，地下街に おける最大加速度は, 地下街の左端で $1605.5 \mathrm{gal}$ (発 生時刻 8.40 秒)，右端で $1615.6 \mathrm{gal}$ （発生時刻 8.40 秒）であった. b) 高層ビルの変位挙動

高層ビル A と高層ビル B の頂部が最も接近した時 の 2 棟の変位挙動を図-8に示す. 同様に，2 棟のビ ルが最も遠ざかった時の変位挙動を図-9に示す.

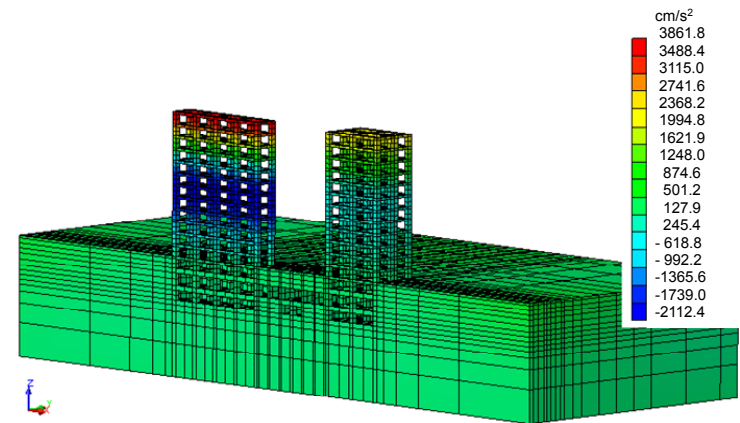

図-6 時刻 3.43 秒における中央断面の最大加速度分布

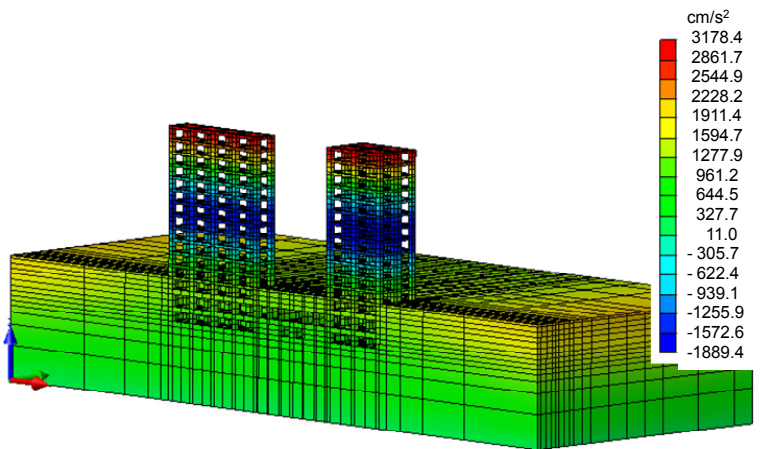

図-7 時刻 8.69 秒における中央断面の最大加速度分布

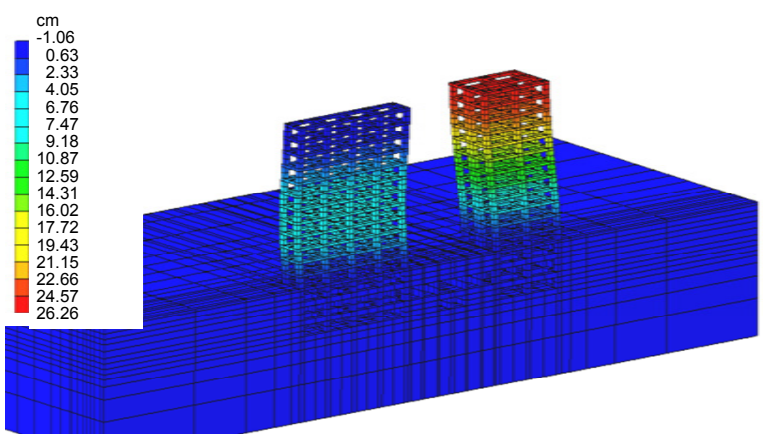

図-82 棟のビル頂部が最も接近した時の変位挙動

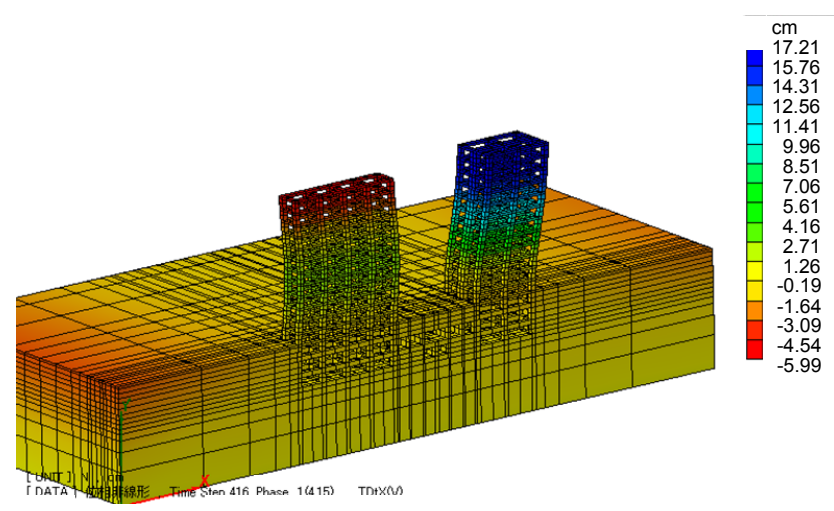

図-92棟のビル頂部が最も遠ざかった時の変位挙動 


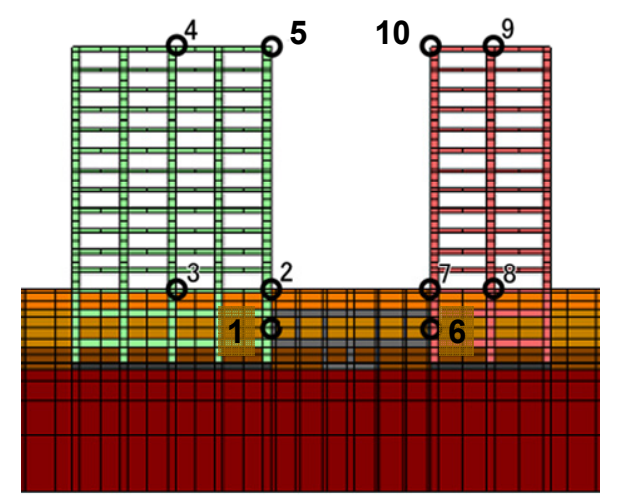

（備考） 位置 $5:$ 高層ビルAの頂部右端 位置 $10 ：$ 高層ビルBの頂部左端 位置 $1:$ 高層ビルAと地下街の接続部 位置 $6:$ 高層ビルBと地下街の接続部

図-10 変位時刻歴の代表出力位置

表-4 代表出力位置での最大変位

\begin{tabular}{|c|c|c|c|c|}
\hline 位置 & $\begin{array}{c}\text { 最大変位 } \\
(\mathrm{cm})\end{array}$ & $\begin{array}{c}\text { 発生時刻 } \\
(\mathrm{s})\end{array}$ & $\begin{array}{c}\text { 最小変位 } \\
(\mathrm{cm})\end{array}$ & $\begin{array}{c}\text { 発生時刻 } \\
(\mathrm{s})\end{array}$ \\
\hline 1 & 3.07 & 9.45 & -3.45 & 3.17 \\
\hline 2 & 3.39 & 9.45 & -4.75 & 3.19 \\
\hline 3 & 3.38 & 1.32 & -4.97 & 3.19 \\
\hline 4 & 27.0 & 1.55 & -37.0 & 1.98 \\
\hline 5 & 27.1 & 1.55 & -37.1 & 1.98 \\
\hline 6 & 3.12 & 9.45 & -3.48 & 8.41 \\
\hline 7 & 3.98 & 9.46 & -4.33 & 3.18 \\
\hline 8 & 4.01 & 9.46 & -4.50 & 8.41 \\
\hline 9 & 31.7 & 1.58 & -38.6 & 3.47 \\
\hline 10 & 31.8 & 1.58 & -38.7 & 3.47 \\
\hline
\end{tabular}

（備考）正は右方向への変位, 負は左方向への変位, 出力位置は図-10参照

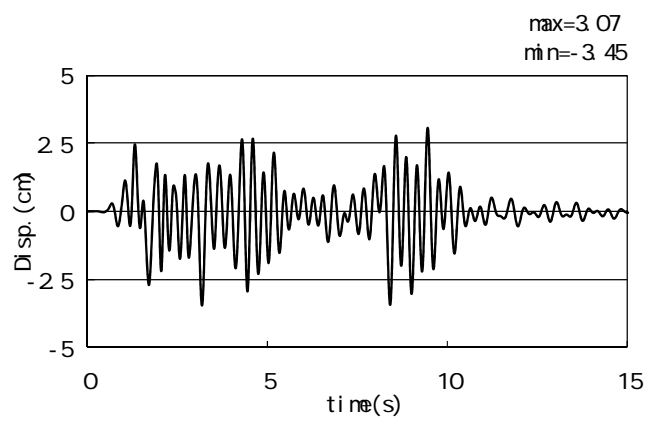

図-11 高層ビル A と地下街左端の接続部の 変位時刻歴（位置 1)

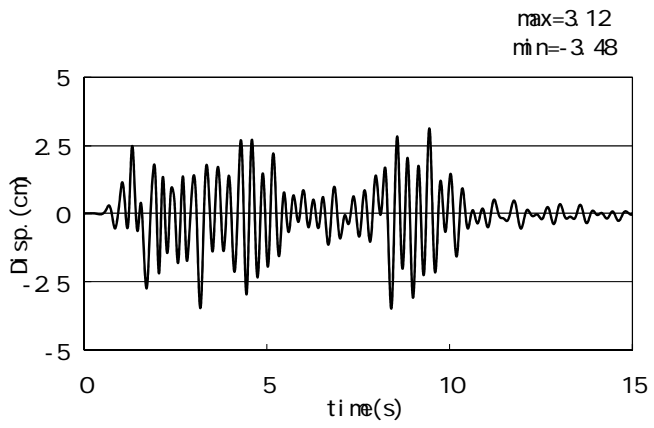

図-12 高層ビル B と地下街右端の接続部の 変位時刻歴（位置 6)
図-10は，変位時刻歴の代表出力位置であるが, 代表出力位置の最大変位量を表-4に示す。また, 図-10に示した，位置 1 , 位置 6 , 位置 5 および位置 10 における変位時刻歴を図-11 から図-14に示す.

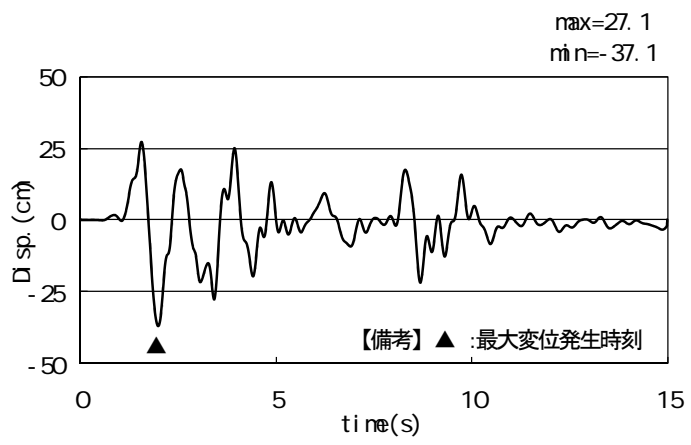

図-13 高層ビル Aの頂部右端の 変位時刻歴（位置 5)

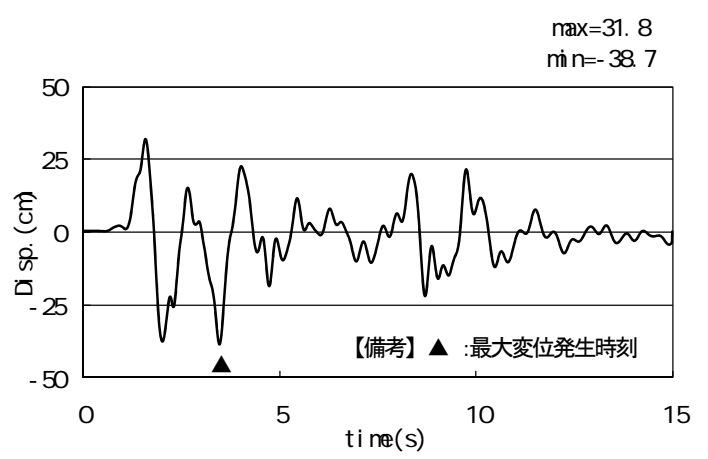

図-14 高層ビル B の頂部左端の 変位時刻歴（位置 $10 ）$

高層ビル A と高層ビル $\mathrm{B}$ の頂部の最大変位量は, それぞれ $37.1 \mathrm{~cm}$ (発生時刻 1.98 秒) と $38.7 \mathrm{~cm}$ (発 生時刻 3.47 秒) であった. また, 地下街の左端およ び右端の最大変位量は，それぞれ $3.45 \mathrm{~cm}$ (発生時刻 3.17 秒）と $3.48 \mathrm{~cm}$ (発生時刻 8.41 秒) であった。

図-8 と図-9 から明らかなように，地下街の両側 に建つ 2 棟の高層ビルは, いつも同じ位相で変位挙 動するのではなく, 時刻によって逆位相で変位挙動 することが分かる，逆位相で変位挙動する場合， 2 棟の高層ビルが近づくモードの時は地下街が高層ビ ルに挟まれるようになることから地下街では圧縮応 力が増大する. 一方, 2 棟の高層ビルが遠ざかるモ ードの時は，地下街が高層ビルによって引つ張られ るようになることから地下街では引張応力が増大す ることになる。

\section{c）地下街と高層ビルの接続部の地震時応力}

全時刻を通しての高層ビルと地下街の周辺の地震 時の最大応力分布を図-15 に示す。高層ビルと地下 街の接続部を拡大した最大応力分布は図-16 に示す 
とおりである. 図-17 に示した出力位置での地震時 の最大主応力の值は表-5 に示すとおりである. 地 下街と高層ビルの接続部に着目した場合, 地下街と 高層ビル A の接続部の最大引張応力は $4.01 \mathrm{~N} / \mathrm{mm}^{2}$ と なり, 地下街と高層ビル B の接続部の最大引張応力 は 4.90N/ $\mathrm{mm}^{2}$ となった. 図-15 と図-16 から, 地下 街と高層ビルの接続部では, 地震時応力が大きくな ることが分かる.

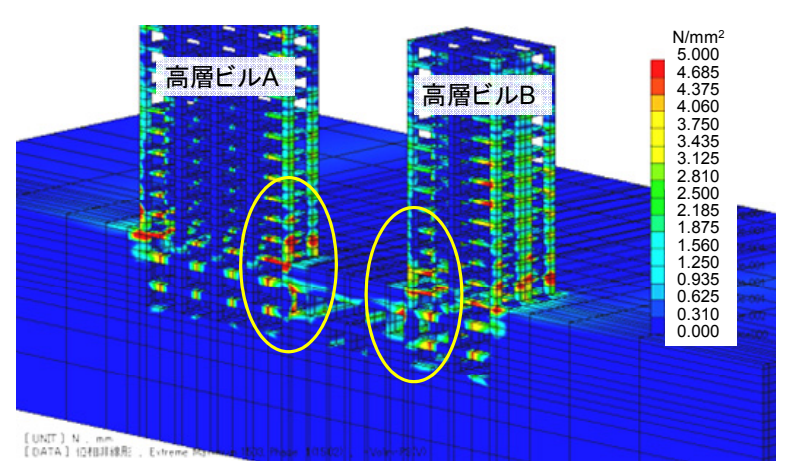

図-15 地震時の最大主応力の分布（全体図）

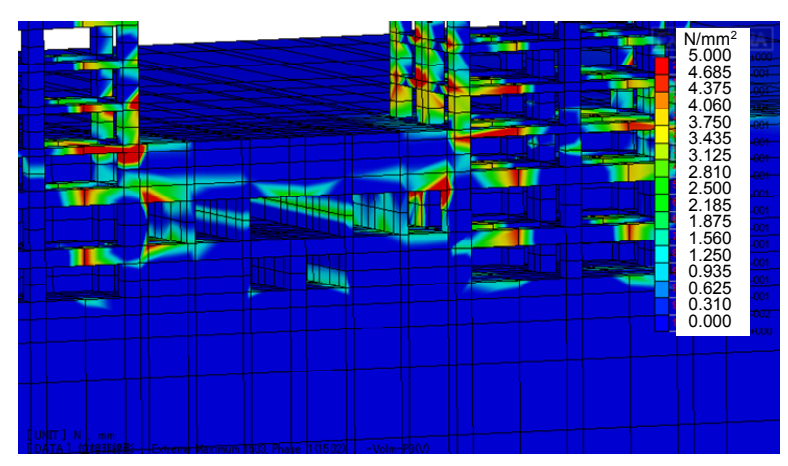

図-16 地下街と高層ビルの接続部の地震時の 最大主応力の分布（地下街拡大図）

地下の地盤内に地下構造物だけが独立して存在す る場合, 通常, 地下構造物は周辺の地盤に拘束され た状況下での地震時応答を示すと考えられる. それ に対して, 地下構造物の両側に高層ビルが建ってい る場合は, 高層ビルと地下構造物は位相と変位振幅 の両面で異なった地震時応答を示すようになり, 高 層ビルの地震時変位挙動の影響を受けて地下構造物 内に発生する地震時応力は増大すると考えることが できる. 高層ビルと地下街の接続部の地震時応力に 関しては, 高層ビル A と地下街の接続部よりも高層 ビル B との接続部において地震時応力が大きい傾向 がある. これは, 高層ビルの平面形状と長辺方向 の関係から, 高層ビル A に比して, 高層ビル B の 方が地下街の横断方向に摇れ易いため, それに伴っ
て地震時応力が大きくなったものと考えられる.

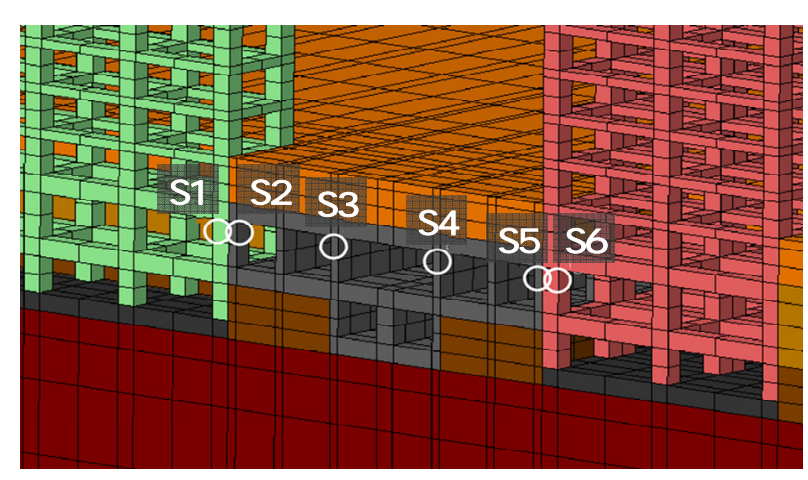

図-17 最大主応力の出力位置

表-5 代表出力位置での地震時の最大主応力

\begin{tabular}{|c|c|}
\hline 出力位置 & 最大主応力 $\left(\mathrm{N} / \mathrm{mm}^{2}\right)$ \\
\hline S1 & -0.53 \\
\hline S2 & 4.01 \\
\hline S3 & -0.47 \\
\hline S4 & 0.54 \\
\hline S5 & 4.90 \\
\hline S6 & 3.55 \\
\hline
\end{tabular}

（備考）出力位置は図-17参照. 正は引張，負は圧縮）

\section{5 . 結論と考察}

1) 地下街に 対する高層ビルの地震時挙動の影響

地下街に対する高層ビルの地震時挙動の影響を模 式的にまとめた結果を図-18 から図-20に示す. 図18 は, 2 棟の高層ビルが同位相で変位挙動する場合 である. 2 棟のビルが同じ方向に変位挙動している 場合は, 地下街の両端では大きな相対変位が発生し ないため応力の増大に対する変位挙動の影響は小さ い. 図-19 と図-20は，2棟の高層ビルが逆位相で変 位挙動する場合であり, 図-19 は, ビルが近づくモ ードを模式的に示したものである. この場合, 地下 街は両側のビルに圧縮されるため地下街では圧縮応 力が増大することになる．ビルが遠ざかるモードの 場合は, 図-20 に示したように, 地下街では引張応 力が増大することになる. これまでの解析的検討に より, 地下街に発生する地震時応力は, 隣接する高 層ビルの地震時挙動の影響を受けて変化することを 確認することができた。

2) 隣接する 構造物間の相互影響を考慮した而震 性能照査の必要性

近い将来, 東海地震, 東南海 - 南海地震, 首都圈 直下地震等の発生が想定されている.これら地震の 発生が想定されている本州太平洋側には, 大都市が 
多く分布し地下街や地下鉄等の利用が進んでいる. 本解析の結果から, 地下構造物の耐震性能照査の精 度・信頼性を向上させるためには, 個々の地下構造 物のみに着目した, 個別的な耐震性能照査では不十 分であり, 隣接する構造物との地震時の相互影響を 考慮した, 総合的な耐震性能照査が必要であると考 察することができる. 大規模な地震災害の特徵は広 域性と同時多発性にあると考えられ，大都市では地 下構造物，地上構造物を問わず，多種多様な構造物 や施設が複合的に隣接している場合が多いので, 隣 接した構造物群の地震時の相互影響を考慮した耐震 性能照査が必要であると考えられる。

3) 地下街と高層ビルの接続部の地震対策について の考察

地下街と高層ビルの接続部のように, 構造物の形 状や地震時変位挙動が異なる構造物の接続部では, 地震時に大きな応力が発生することが想定される. このような場合, 構造物と構造物の接続部に非連続 的挙動 (剥離, 滑動) が可能なジョイントを配置す ることによって, 接続部で地震時応力を解放する軽 減することができるものと考察される.

4) 今後の課 題

入力地震動の加振方向の影響, 地下街と高層ビル の接続部の非連続的挙動（剥離や開口）の影響, 地 盤の動的変形特性（動的せん断剛性, 減衰定数等) の影響等について, 今後も研究を深めて行くことが 必要であると考えている.

\section{6. おわりに}

多種多様の構造物が高密度に建設されている大都 市では, 大地震の際に隣接する構造物や連結された 構造物の間で様々な相互影響が発生する可能性があ ると考えられる. 大都市の地震防災性能を向上させ るためには, 隣接する構造物の間の相互影響を考慮 した耐震性能照査と地震対策を推進して行くことが 必要である.

謝辞：解析プログラムのラン作業に際しては, JIP テクノサイエンス（株）の竹原和夫氏, 赤坂和彦氏 に多くのご協力をいただきました。記して感謝の意 を表します。

\section{参考文献}

1) 有賀義明：軟弱地盤を利用した免震効果の可能性につ いて, 土木学会第 20 回地震工学研究発表会, No.56, pp.221-224, 1989

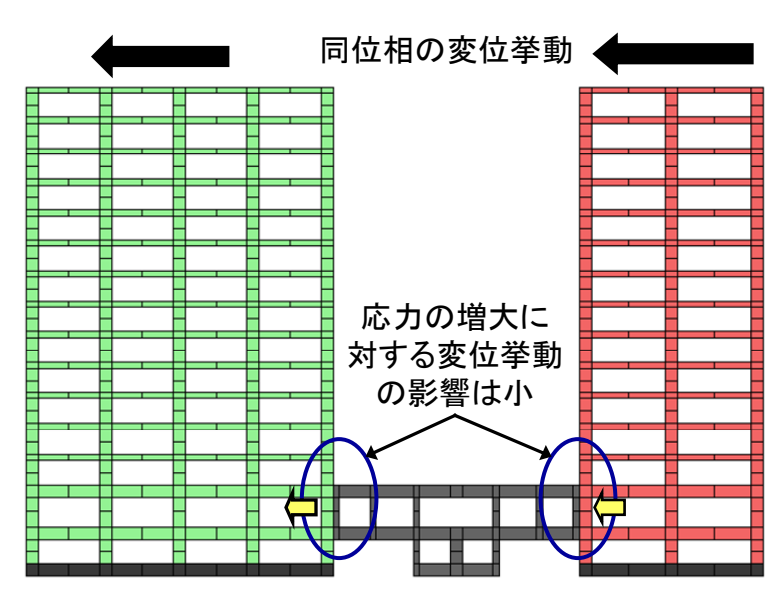

図-18 地下街に対する高層ビルの影響

（高層ビルの変位挙動が同位相の場合）

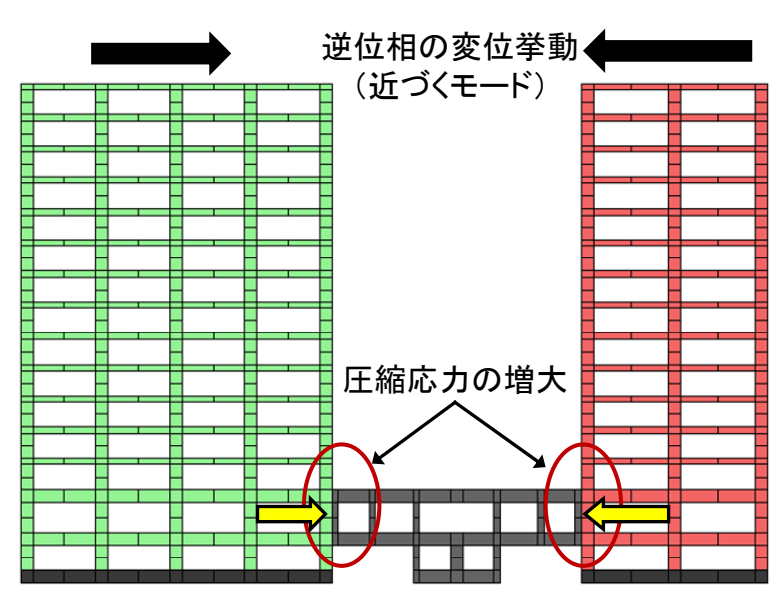

図-19 地下街に対する高層ビルの影響 （高層ビルが逆位相で近づく場合）

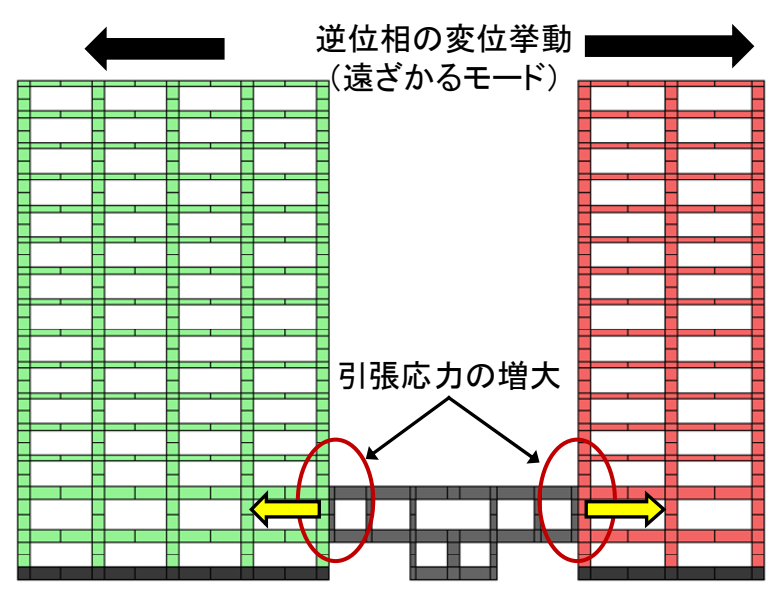

図-20 地下街に対する高層ビルの影響 （高層ビルが逆位相で遠ざかる場合）

2) 有賀義明 : 地下に低速度が介在する地盤の地震動伝播 特性, 土木学会第 43 回年次学術講演会, I - -473, pp.996997, 1988 
3) 中村晋：地震被害程度の差異に着目した地下鉄の被害 要因分析, 土木学会論文集 654 巻, I -52 号, pp.335354,2000

4) 和泉正哲：1985 年メキシコ地震に関する調査研究, 自 然災害特別研究突破突発災害研究成果 No.B-60-6, 1986

5) 大深度地下の公共的使用に関する特別措置法, 平成 12 年, 法律第 87 号

6) 土木学会:コンクリート標準仕方書耐震性能照査編, pp.47, 2002

7) 国土交通省 : 大深度地下使用技術指針・同解説，2001

8) 国土交通省：大深度地下の公共的使用における安全確 保に係る指針，2004

9) 日本学術会議：勧告 大都市における地震災害時の安全 の確保について，2005

（原稿受理2010年7月23日）

\section{EFFECTS OF EARTHQUAKE BEHAVIORS OF HIGH BUILDINGS ON SEISMIC SAFETY OF UNDERGROUND SHOPPING ARCADE}

\section{Yoshiaki ARIGA, Yuusuke HIRANO, Keinosuke INOKO, Mikio TAKEUCHI, Akira OGURO, Hiroyuki ASAKA, Masaaki MURAKAMI}

Generally, the underground is thought to be safer than the ground, because the acceleration amplitudes of earthquake motions tend to be smaller in the underground. However, it is considered that the seismic safety of structures will largely affected by the mutual effects between the ground structure and the underground structure during earthquakes. Then, we made 3-D dynamic analyses regarding the coupled subway - underground shopping arcade - high building system in order to evaluate the effects of earthquake behaviors of high buildings on the underground shopping arcade. As a result, it is considered that the high buildings will behave out of phase with each other, and that the dynamic stresses around the connecting parts between the underground shopping arcade and the high buildings will be largely changed by the displacement behaviors of high buildings. In order to realize earthquake disaster prevention in urban area, mutual effects between the underground structures and the ground structures shall be taken into account. 